International Journal of English Literature and Social Sciences
Vol-6, Issue-5; Sep-Oct, 2021

Peer-Reviewed Journal

\title{
The Impact of Adobe Flash Media on Increasing Students' Critical Thinking Ability
}

\author{
Elma Ayu Nur Fandini, Siswandari, Kristiani
}

Master of Economic Education, Faculty of Teacher Training and Education, Sebelas Maret University, Indonesia

Received: 11 Aug 2021; Received in revised form: 07 Sep 2021; Accepted: 16 Sep 2021; Available online: 21 Sep 2021

(C)2021 The Author(s). Published by Infogain Publication. This is an open access article under the CC BY license

(https://creativecommons.org/licenses/by/4.0/).

\begin{abstract}
Learning in Industrial Revolution Era 4.0 is plotted to integrate the use of technology and information optimally. The optimal use of technology and information is intended to develop students' critical thinking skills. However, it is known that the use of media in economics learning in high school is still not optimal, so students' critical thinking skills are not optimally developed. This study aims to examine the impact of the use of adobe flash media in improving students' critical thinking skills. The study employed the quasi-experimental research method, and cluster random sampling is used to determine the experimental group and the control group. The results of this study demonstrate that adobe flash media has a significant effect on increasing students' critical thinking skills in economic learning. It is indicated by the acquisition of $t=0,000$ with a significance level of $<0.05$. Furthermore, the average critical thinking ability of students in the experimental class increased by 22 points after learning using adobe flash media. In addition, the average critical thinking ability of students in the experimental class was 8 points higher than the students in the control class.
\end{abstract}

Keywords-Critical Thinking Skills, Adobe Flash Media.

\section{INTRODUCTION}

Learning quality can be recognized from two different aspects; results and the learning process. Learning is considered successful if the learning outcomes and learning process indicate that at least $75 \%$ of students can master the learning material and are actively involved in the learning process. Many schools have used the 2013 curriculum. However, the learning process is still teachercentered. Hence, such a condition does not help to sharpen students' critical thinking skills to the fullest. Moreover, we are now in the learning of the industrial revolution era 4.0 (21st Century), which is an era integrating technology and information in various sectors. In 21 st century learning, students are required to have critical thinking skills. This is necessary since people must be able to respond to changes quickly and effectively so that they need an intellectual ability that is flexible. Also, people need analytical skills to integrate multiple sources to solve problems.
Critical thinking skill is one of the most crucial competencies that students should possess. It becomes an important aspect that a teacher needs to develop for students as a provision for life in the future (Maryuningsih, Hidayat, Riandi \& Rustaman, 2019). It is due to the fact that critical thinking skills can improve students' ability to analyze and match problems. The benefits of training students' critical thinking skills are to equip students to have the ability to solve problems, make decisions, and never stop learning (Afandi \& Sajidan, 2018: 129), so that they can survive in the future (Maryuningsih, Hidayat, Riandi \& Rustaman, 2019; Rohm, Stefl \& Saint, 2019; Sarwi, Ellianawati \& Suliyanah, 2019; Slocum, Dimitrov $\&$ Webb, 2019), and provide the best results in real-world practice (Steel, Peng, Gray \& Adams: 2019).

The ability to think critically allows students to think in various aspects or disciplines, which can be used to fulfill intellectual needs, as well as students' potential for careers and life in the real world. Regarding 
economics learning, it is essential to have critical thinking skills because economics is a science that studies human behavior pertinent to the real world. Therefore, it requires an analytical process, an ability to think logically, and intensive thinking.

Based on a preliminary study conducted with economics teachers in high school, it was found that the use of learning media and information technology was still not optimal. In this regard, teachers had not implemented student-centered learning so that the level of students' critical thinking skills was relatively low. This can be seen in the data on the results of the National Examination for economics in 2019 showing an average value of 66.56. In addition, the researchers also found that the average critical thinking ability test results of students in the preliminary study were still relatively low, with an average of $60.76 \%$.

There are still many students who get scores below the Minimum Completeness Criteria, which is 75 . The low critical thinking ability of students can be caused by the lack of innovation and creativity of teachers in utilizing technology and information learning media so that students feel less interested and have difficulty understanding the material presented by the teacher in the economics learning process.

The presence of media in the learning process has induced a very positive impact on student activity to help improve students' critical thinking skills. Wicaksono (2016) asserted that the world of education requires the development of hardware and software technology that has a positive impact on the use of teaching aids. Besides, learning media are also referred to as tools that teachers can use as intermediaries between message senders and recipients (Widodo \& Wahyudin; 2018). Learning media is divided into two based on technological developments, namely traditional media (audio recording media, print media) and advanced technology media (telecommunication - based media, microprocessor - based media) (Widodo \& Wahyudin, 2018).

Adobe Flash is a software that can be used to create learning media and is equipped with animation applications with spectacular effects (Idriani \& Amna; 2019). Kartini and Kantun (2018) elaborated that the application of learning media using Adobe Flash can provide good pictorial animations so that students feel interested in participating in the learning process.

Based on the aforementioned and the relevant research conducted by $\mathrm{T}$ Gayatri, $\mathrm{H}$ Sugiyanto, and $\mathrm{P}$ Ritayati (2018) with the title Development of Contextual Teaching Audio Visual Learning Based on Adobe Flash Media to Improve Critical Thinking Skills in Geography
Learning in High School with the results of research and development, it was concluded that the development of CTL-based adobe flash media is carried out using the ADDIE model and using Adobe Flash, which is very feasible. In short, it can improve students' critical thinking skills. Thus, this article will present the results of the research on the effect of adobe flash learning media on the improvement of students.

\section{METHODOLOGY}

The study was conducted as a QuasiExperimental with a Non-randomized Pretest-Posttest with a Control Group approach. The population in this study were students in Social study 1, Social study 2, and Social study 3 of a senior high school, with a total of 105 students. The sampling technique was Cluster Random Sampling with 35 students in each group, consisting of two experimental groups and a control group. In this study, the experimental group was the 3rd grade of Social study which received treatment with adobe flash media, while the control group was the 2nd grade of Social study which did not receive treatment with adobe flash media.

\section{RESULTS AND DISCUSSIONS}

Before experiencing the treatment, both the experimental group and the control group were tested through a pretest. The pretest results in the experimental group and control group are presented in table 1 and table 2.

Table 1. Pretest Value of the Experimental Group

\begin{tabular}{|c|c|c|c|}
\hline Respondent & Score & Respondent & Score \\
\hline 1 & 70 & 19 & 44 \\
\hline 2 & 73 & 20 & 50 \\
\hline 3 & 51 & 21 & 56 \\
\hline 4 & 73 & 22 & 49 \\
\hline 5 & 51 & 23 & 60 \\
\hline 6 & 52 & 24 & 65 \\
\hline 7 & 61 & 25 & 70 \\
\hline 8 & 57 & 26 & 60 \\
\hline 9 & 70 & 27 & 70 \\
\hline 10 & 75 & 28 & 65 \\
\hline 11 & 55 & 29 & 72 \\
\hline 12 & 65 & 30 & 63 \\
\hline 13 & 72 & 31 & 68 \\
\hline 14 & 59 & 32 & 59 \\
\hline & & & \\
\hline
\end{tabular}




\begin{tabular}{|c|c|c|c|}
\hline 15 & 67 & 33 & 68 \\
\hline 16 & 63 & 31 & 71 \\
\hline 17 & 55 & 35 & 49 \\
\hline 18 & 56 & Rata-rata & 61,82 \\
\hline
\end{tabular}

Table 2. Pretest Value of Control Group

\begin{tabular}{|c|c|c|c|}
\hline Respondent & Score & Respondent & Score \\
\hline 1 & 56 & 19 & 55 \\
\hline 2 & 62 & 20 & 62 \\
\hline 3 & 69 & 21 & 57 \\
\hline 4 & 68 & 22 & 59 \\
\hline 5 & 78 & 23 & 60 \\
\hline 6 & 72 & 24 & 56 \\
\hline 7 & 40 & 25 & 50 \\
\hline 8 & 48 & 26 & 62 \\
\hline 9 & 45 & 27 & 69 \\
\hline 10 & 50 & 28 & 60 \\
\hline 11 & 46 & 29 & 61 \\
\hline 12 & 45 & 30 & 70 \\
\hline 13 & 50 & 31 & 56 \\
\hline 14 & 55 & 32 & 63 \\
\hline 15 & 65 & 33 & 44 \\
\hline 16 & 42 & 31 & 65 \\
\hline 17 & 45 & 35 & 70 \\
\hline 18 & 65 & Rata-rata & 57,71 \\
\hline
\end{tabular}

After being treated with Adobe Flash media, the experimental group and the control group were tested again with a post-test. This is to determine the improvement of students' critical thinking skills through the learning outcomes. The post-test results in the experimental group and control group are presented in table 3 and table 4 .

Table 3. Posttest Value of the Experimental Group

\begin{tabular}{|c|c|c|c|}
\hline Respondent & Score & Respondent & Score \\
\hline 1 & 90 & 19 & 75 \\
\hline 2 & 91 & 20 & 78 \\
\hline 3 & 79 & 21 & 82 \\
\hline 4 & 84 & 22 & 76 \\
\hline 5 & 77 & 23 & 80 \\
\hline
\end{tabular}

\begin{tabular}{|c|c|c|c|}
\hline 6 & 75 & 24 & 83 \\
\hline 7 & 79 & 25 & 90 \\
\hline 8 & 76 & 26 & 79 \\
\hline 9 & 92 & 27 & 95 \\
\hline 10 & 95 & 28 & 84 \\
\hline 11 & 80 & 29 & 93 \\
\hline 12 & 86 & 30 & 84 \\
\hline 13 & 88 & 31 & 87 \\
\hline 14 & 83 & 32 & 90 \\
\hline 15 & 81 & 33 & 86 \\
\hline 16 & 90 & 31 & 89 \\
\hline 17 & 78 & 35 & 79 \\
\hline 18 & 85 & Rata-rata & 83,97 \\
\hline
\end{tabular}

Table 4. Posttest Value of Control Group

\begin{tabular}{|c|c|c|c|}
\hline Respondent & Score & Respondent & Score \\
\hline 1 & 60 & 19 & 60 \\
\hline 2 & 65 & 20 & 69 \\
\hline 3 & 74 & 21 & 86 \\
\hline 4 & 75 & 22 & 66 \\
\hline 5 & 80 & 23 & 75 \\
\hline 6 & 75 & 24 & 80 \\
\hline 7 & 74 & 25 & 86 \\
\hline 8 & 75 & 26 & 70 \\
\hline 9 & 55 & 27 & 76 \\
\hline 10 & 60 & 28 & 68 \\
\hline 11 & 70 & 29 & 72 \\
\hline 12 & 74 & 30 & 90 \\
\hline 13 & 69 & 31 & 73 \\
\hline 14 & 75 & 32 & 75 \\
\hline 15 & 50 & 33 & 80 \\
\hline 16 & 83 & 31 & 78 \\
\hline 17 & 56 & 35 & 72 \\
\hline 18 & 70 & Rata-rata & 71,88 \\
\hline
\end{tabular}

Both pre-test and post-test data of the experimental group and control group were tested for normality by using Kolmogorov Smirnov, and homogeneity test was conducted by using Levene's Test. The results of the pretest of normality test of the experimental group and the control group showed that the 
sig value was $0.200>0.05$. Furthermore, the post-test of the normality test showed a significance of $0.200>0.05$. Accordingly, it is concluded that the data is normally distributed. The results of the pretest of homogeneity test of the experimental group and the control group showed that the significance value was $0.481>0.05$, and the posttest significance value was $0.116>0.05$. Thus, it is considered that the variance is homogeneous.

Since the data have been known to be normal and homogeneous, the effectiveness was tested by using the Ttest. The results of the tests conducted by the researchers found that the pretest score for the critical thinking ability of the experimental group students was 61.83, and the control group was 57.72. Meanwhile, the post-test value of the experimental group was 83.97, and the control group was 71.88 . The results of the T-test were obtained with a significance value of $0.000<0.05$. This concluded that there is a significant difference between the critical thinking abilities of the experimental group students and the control group after the treatment. Based on the value of students' critical thinking skills given before and after learning in the experimental group and control group, there was an increase of 22.14 for the experimental group and 14.16 for the control group. Therefore, it is confirmed that the improvement of students' critical thinking skills in the experimental group is 8 points higher than that of the control group.

\section{CONCLUSIONS}

Based on the results, it can be concluded that the use of adobe flash media has a significant effect on increasing students' critical thinking skills in economics learning. It is indicated by the acquisition of $\mathrm{t}=0,000$ with a significance level of $<0.05$. Furthermore, the average critical thinking ability of students in the experimental class increased from 14,16 to 22.14 points after learning by using adobe flash media. In addition, the average critical thinking ability of students in the experimental class was 8 points higher than the students in the control class. Thus, it is concluded that the adobe flash media is considered effective in increasing students' critical thinking skills in economics learning.

\section{REFERENCES}

[1] Wicaksono, Satriyo. (2016). The development of interactive multimedia based learning using macromedia flash 8 in accounting course. Journal of accounting and business education. 1 (1)

[2] Widodo, S.A., \& Wahyudin. (2018). Selection of Learning Media Mathematics for Junior School Students. The Turkish Online Journal of Educational Technology. 17 (1)
[3] Idriani, S., \& Amna, S. (2019). Designing a Learning Media of English for Specific Purpose based on Interactive Multimedia (Macromedia flash 0.8) for Agro-Industry Students. Jurnal Arbitrer. 6 (2), 137-146.

[4] Farhan, A.A., Kartini.T., \& Kantun, S. (2018)_Penggunaan Media Pembelajaran Adobe Flash Cs 6 Untuk Meningkatkan Minat Dan Hasil Belajar Siswa Pada Kompetensi Dasar Mendeskripsikan Sistem Pembayaran Dan Alat Pembayaran. Jurnal Ilmiah Ilmu Pendidikan, Ilmu Ekonomi, dan Ilmu Sosial. 12 (1). 2548-7175

[5] Gayatri, T., Sugiyanto, H., \& Ritayati, P. (2018). Development of Contextual Teaching Learning-Based Audio Visual Adobe Flash Media to Improve Critical Thinking Ability of Geography Learning at Senior High School. IOP Conf. Series: Earth and Environmental Science. Doi :10.1088/1755-1315/145/1/012004

[6] Maryuningsih, Y., Hidayat, T., Riandi, R., \& and Rustaman, N.Y. (2018). Critical thinking skills of prospective biology teacher on the chromosomal basic of inheritance learning through online discussion forums. Journal of Physics: Conference Series. 1157 (2), 1-6

[7] Afandi \& Sajidan. (2018). Stimulasi Keterampilan Berpikir Tingkat Tinggi: Konsep dan Implementasinya dalam Pembelajaran Abad 21. Surakarta: UNS Press

[8] Rohm, A.J., Stefl, M., \& Saint Clair, J. (2019). Time for a Marketing Curriculum Overhaul: Developing a Digital-First Approach. Journal of Marketing Education. 41(1), 47-59 Ekonomi Pada Siswa Kelas X IIS 1 Di Sma Islam Kepanjen Semester Genap Tahun Ajaran 2013/2014. Jurnal Pendidikan Ekonomi. 8 (2). 96-107

[9] Sarwi, S., Ellianawati, E., \& Suliyanah. (2019). Grounding physics and its learning for build- ing global wisdom in the 21st century. Journal of Physics: Conference Series. 1171(1) 012001

[10] Slocum, S.L., Dimitrov, D.Y., \& Webb, K. (2019). The impact of neoliberalism on higher education tourism programs: Meeting the 2030 sustainable development goals with the next generation. Tourism Management Perspectives. 30, 33-42

[11] Steel, A., Peng, W., Gray, A., \& Adams, J. (2019). The Role and Influence of Traditional and Scientific Knowledge in Naturopathic Education: A Qualitative Study. The Journal Of Alternative And Complementary Medicine. Vol 25 (2), 196-201. 